\title{
Ostracoda of the Italian ricefields thirty years on: new synthesis and hypothesis
}

\author{
Valeria ROSSI*, Giorgio BENASSI, Marco VENERI, Carlo BELLAVERE, Paolo MENOZZI, Antonio MORONI \\ and Kenneth Glencoe McKENZIE ${ }^{1)}$
}

Department of Environmental Sciences, University of Parma, Parco Area delle Scienze 11/A, I-43100 Parma (Italy)

${ }^{1)}$ School of Science and Technology, CSU-R, Wagga Wagga 2678 (Australia)

*e-mail corresponding author: valeria.rossi@unipr.it

\begin{abstract}
We compare data from a survey of ostracode species carried out during 1994-1998 from Northern Italian ricefields with data from the same area collected in the '60s. Twenty-five species were recorded during a survey of 19 ricefields in 1994-98 as against 46 species found in 16 ricefields over thirty years ago. Three of these species (Ilyocypris biplicata, Chlamydotheca incisa and Chrissia sp.), as well as six among the 27 species found in the '60s but not recorded during 1994-1998, were found in Italy only in the ricefield habitat. Three species were recorded for the first time in Italy: Hemicypris dentatomarginata, Ilyocypris monstrifica and Chrissia $s p$. Eight taxa (Chlamydotheca incisa, Chrissia $s p$., Cypretta turgida, Dolerocypris sinensis, H. dentatomarginata, Isocypris beauchampi, Strandesia spinulosa and Tanycypris pellucida) were considered endemic to South America, Africa or Asia and are thought to have been introduced to Italy with useful plants, notably rice varieties. The recording of these species indicates once again the importance of man as an agent for passive dispersal of ostracode and the role of ricefields as a suitable habitat for new exotic colonising species. Heterocypris incongruens is the most widespread species and several other species (D. sinensis, Cypridopsis vidua, Ilyocypris gibba and Isocypris beauchampi cicatricosa) were found in more than 50\% of the ricefields sampled: 40\% of the species occur in just one or two ricefields. In Northern Italy today, species similarity between ricefields is inversely related to their geographic distance but is not spatially structured. This may be due to the fact that, in ostracodes, the production of passive dispersal resting eggs constrains regional differentiation. Species richness is significantly related to the amount of cultivated area. The decrease in species richness observed over the last thirty years or so may be related to the widespread use of pesticides in local current agricultural practices.
\end{abstract}

Key words: species richness, geographic distance, dispersal

\section{INTRODUCTION}

A considerable amount of effort was devoted to describing the taxonomy and distribution of recent freshwater ostracodes in Italy by Prof. A. Moroni (1967a, b, c) during the $1950 \mathrm{~s}$ and the early '60s. His work was complemented by the publication of a guidebook for the identification of Italian freshwater ostracodes (Ghetti \& McKenzie 1981) and a list of ricefield species (McKenzie \& Moroni 1986). Further data on the Recent freshwater ostracodes of Italy are relatively scarce.

Many Italian species are known only from temporary habitats. Their success depends on survival through the dry period by resting eggs and diffusion, specially for Cypridoidea, via a passive dispersal by birds, wind, and with the seeds of useful plant (McKenzie \& Moroni 1986; Baltanas 1992). Moreover, their colonisation is extremely efficient because of the parthenogenetic mode of reproduction that is typical of most non-marine ostracodes (Martens 1998). Nevertheless, passive dispersal cannot completely explain recent distribution patterns of freshwater ostracodes and local interactions among species, abiotic factors and anthropogenic influences likely also affect species richness and dispersal (Victor \& Fernando 1982; Shurin et al. 2000; Bilton et al. 2001). Historical events must also have played an important role. In 1986, McKenzie \& Moroni discussed the dispersal of ostracode species via rice (Oryza sativa) and reported the presence of "ospiti esteri" in the Italian ricefields. Of a total of 46 species they recorded, 13 were species foreign in origin but occurring in Italy particularly in the ricefields habitat. Most of these species are Asian and are supposed to have been introduced in Italy along with such useful plants as rice and hemp (McKenzie \& Moroni 1986). The cultivation in Italy of tobacco, maize, tomato, capsicum and chilis might well account for the occasional presence of South American "ospiti esteri" such as Chlamydotheca incisa; the Australian species Ilyodromus viridulus likely arrived in Northern Italy with rice seed introduced for experimental purposes. Isocypris is an endemic African genus now represented also by several Recent European species (Fox 1963). It has no fossil record in Europe, where no bisexual populations are known. It possibly arrived in Europe with Egyptian wheat or cotton or even with gold dust from Central Africa, diversifying subsequently from the African species.

Ricefields are temporary, summer, environments characterised by rapid physical and chemical changes, ecological succession and a relatively brief history. In European countries, ricefield ecosystems are characterised by periodical cycles of submersion and drying. In 


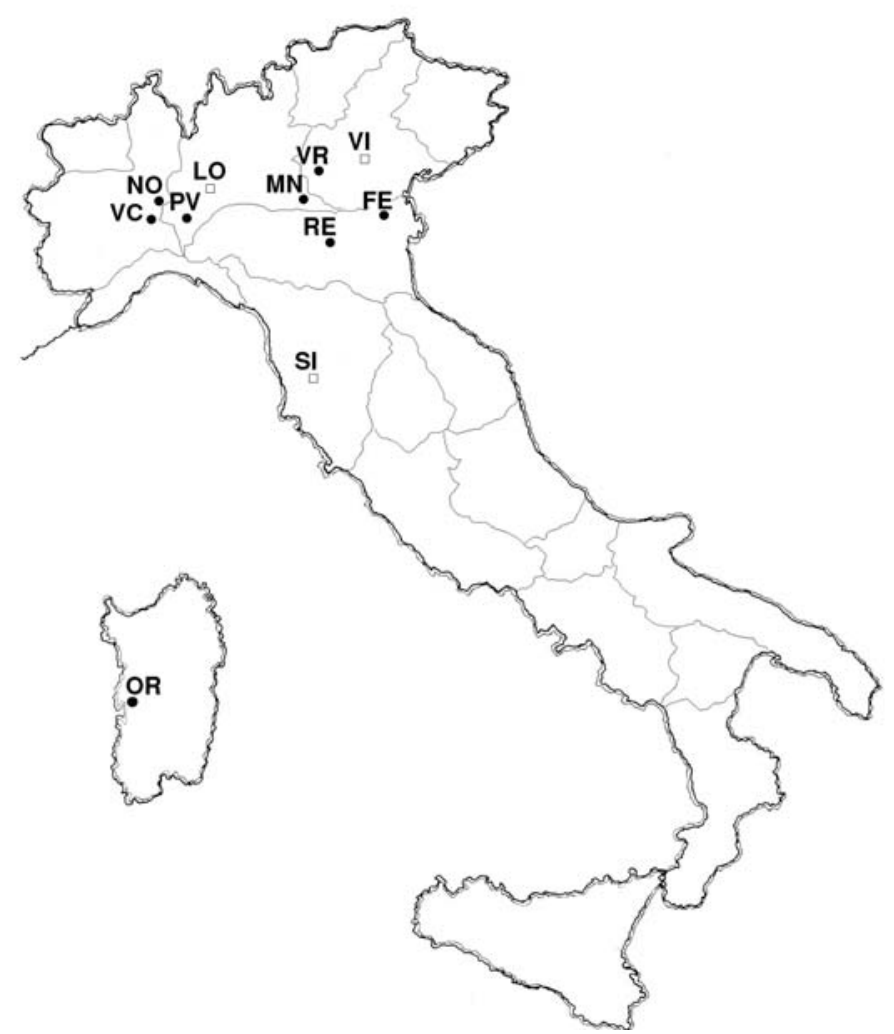

Fig. 1. Locations of the 19 Italian ricefields studied in the '90s: 1 Saluggia (VC), 2 Livorno Ferraris (VC), 3 Murone Nord (VC), 4 Murone Sud (VC), 5 Briona (NO), 6 Castellazzo (NO), 7 Orfengo di Casalino (NO), 8 Gionzana (NO), 9 Bellinzago (NO), 10 Cameri (NO), 11 Sannazzaro (PV), 12 Cascinotto (PV), 13 Torrebianca (PV), 14 La Bigliana (RE), 15 Villa Garibaldi (MN), 16 Vigasio (VR), 17 Jolanda di Savoia (FE), 18 Pontile (OR), 19 Cabras (OR). In the '60s, 16 ricefields were studied: Lamporo (VC), Desana (VC), Barze (NO), Briona (NO), Castellazzo (NO), Maina (PV), Olza (LO), S. Antonio (MN), Cortenuova (RE), La Vecchia (RE), Zanella (VR), Cantarella (VI), Pegoraro (VI), Guagnino (FE), Merse (SI), Siviero (OR). Only provinces are reported on the map: full circle indicates provinces sampled in the ' 60 or in the ' 90 , open square indicates provinces sampled only in the ' 60 s.

its aquatic phase, due to low water level and high temperature, a ricefield is characterised by high productivity (Ferrari et al. 1991; Fernando 1993; Leoni et al. 1999). In Northern Italy, a dramatic increase in rice cultivation was achieved between 1853 and 1866 when, in the Vercellese area (Piedmont), a very efficient irrigation system was installed. At present, the Northern Italian ricefields represent an ecosystem of aquatic islands surrounded by a land area of about 200,000 ha, of which 90\% lies between Novara, Vercelli and Pavia (www.enterisi.it), encompassing much of the Po Plain (Pianura Padana). The analysis of this habitat should be relevant for the evaluation of some very recent events that appear to have affected the richness and biogeography of non-marine ostracodes in Northern Italy. In sum, this paper represents an update of the work that Moroni (1967a, b, c) and, later, McKenzie and Ghetti (Ghetti \& McKenzie 1981; McKenzie \& Moroni 1986) completed a generation ago.

\section{MATERIAL AND METHODS}

Sampling was carried out from 1994 to 1998 , in 19 ricefields (Fig. 1) mainly located in Northern Italy. The qualitative samples were collected by sweeping the water column just above the sediment with a hand net ( $25 \mathrm{~cm}$ diameter, $20 \mu \mathrm{m}$ mesh-size). Samples were fixed in $4 \%$ neutralised formaldehyde, in order to prevent decalcification of ostracode valves and transferred to $70 \%$ methyl alcohol as soon as possible. Dissection, staining and mounting procedure followed Danielopol (1982) using a Wild M8 stereomicroscope and Zeiss optical microscope. Classification of species and their taxonomy is based on: Sars (1928), Klie (1938), Bronshtein (1947), Ghetti \& McKenzie (1981), Meisch (1984, 1985) and Meisch et al. (1990).

\subsection{Statistical analysis}

For data reduction according an optimal scaling procedure, homogeneity analysis by means of alternating least squares (HOMALS) was performed to describe the relationships between two or more nominal variables in a low-dimensional space (Dimension 1 and Dimension 2) containing the variable categories as well as the objects in those categories. This analysis is used to discriminate between ricefields according to their species' composition. 
Tab. 1. Ostracod species occuring in the samples in the '60 (McKenzie \& Moroni 1986) and in the '90 in Northern Italian ricefileds. Each species is distinguished by a numerical code.

\begin{tabular}{|c|c|c|c|c|}
\hline FAMILY & SPECIES & '60 & $' 90$ & Code \\
\hline \multirow[t]{2}{*}{ Limnocytheridae } & Limnocythere inopinata (Baird 1843) & 1 & 1 & 1 \\
\hline & L. cf. stationis Vavra, 1901 & 1 & & \\
\hline \multirow{6}{*}{ Ilyocyprididae } & Ilyocypris inermis Kaufmann 1900 & 1 & & \\
\hline & I. australiensis Sars 1890 & 1 & & \\
\hline & I. biplicata (Koch 1838) & 1 & 1 & 2 \\
\hline & I. decipiens Masi 1906 veneta Moroni 1961 & 1 & 1 & 3 \\
\hline & I. monstrifica Norman 1862 & & 1 & 4 \\
\hline & I. gibba (Ramdohr 1808) & 1 & 1 & 5 \\
\hline \multirow[t]{6}{*}{ Candonidae } & Candona candida (O.F. Müller 1776) & 1 & & \\
\hline & C. neglecta Sars 1887 & 1 & & \\
\hline & Fabaeformiscandona fabaeformis (Fischer 1851) & 1 & & \\
\hline & F. fragilis Hartwig 1898 & 1 & & \\
\hline & Pseudocandona albicans (Brady 1864) & 1 & 1 & 6 \\
\hline & Paracandona euplectella (Brady \& Norman 1889) & 1 & & \\
\hline Notodromadidae & Notodromas persica Gurney 1920 dalmatina Petkovski 1959 & 1 & & \\
\hline \multirow[t]{37}{*}{ Cyprididae } & Chlamydotheca incisa (Claus 1892) & 1 & 1 & 7 \\
\hline & Chrissia sp. & & 1 & 8 \\
\hline & Cypretta dubia (Daday 1901) & 1 & & \\
\hline & C. globulus (Sars 1890) & 1 & & \\
\hline & C. seurati Gauthier 1929 & 1 & & \\
\hline & C. turgida (Sars 1895) & 1 & 1 & 9 \\
\hline & Bradleystrandesia fuscata (Jurine 1820) & & 1 & 10 \\
\hline & Cypris pubera O.F. Müller 1776 & 1 & 1 & 11 \\
\hline & Dolerocypris fasciata (O.F. Müller 1776) & 1 & & \\
\hline & D. sinensis Sars, 1903 & 1 & 1 & 12 \\
\hline & Eucypris ornata (O.F. Müller 1776) & 1 & 1 & 13 \\
\hline & E. virens (Jurine, 1820 ) & 1 & 1 & 14 \\
\hline & Hemicypris dentatomarginata (Baird 1859) & & 1 & 15 \\
\hline & Herpetocypris reptans (Baird 1835) & 1 & 1 & 16 \\
\hline & Heterocypris incongruens (Ramdohr 1808) & 1 & 1 & 17 \\
\hline & H. salina (Brady 1868$)$ & 1 & & \\
\hline & Ilyodromus viridulus (Brady 1886) & 1 & & \\
\hline & Isocypris beauchampi cicatricosa Fox 1963 & 1 & 1 & 18 \\
\hline & Psychrodromus olivaceus (Brady \& Norman 1889) & 1 & & \\
\hline & Stenocypris major (Baird 1859) & 1 & 1 & 19 \\
\hline & Strandesia caudata Klie 1939 & 1 & & \\
\hline & S. spinulosa Bronstein in Akatova 1958 & 1 & 1 & 20 \\
\hline & S. tonolli Moroni 1961 & 1 & & \\
\hline & Tanycypris pellucida (Klie 1932) & 1 & 1 & 21 \\
\hline & Trajancypris clavata (Baird 1838) & 1 & 1 & 22 \\
\hline & Prionocypris zenkeri (Chyzer \& Toth 1858) & 1 & & \\
\hline & Cypridopsis elongata Kaufmann 1900 & 1 & & \\
\hline & C. hartwigi G.W. Müller 1900 & 1 & & \\
\hline & C. helvetica Kaufmann 1900 & & 1 & 23 \\
\hline & C. obesa Brady \& Robertson 1869 & 1 & & \\
\hline & C. parva G.W. Müller 1900 & 1 & & \\
\hline & C. vidua (O.F. Müller 1776) & 1 & 1 & 24 \\
\hline & Plesiocypridopsis newtoni (Brady \& Robertson 1870) & & 1 & 25 \\
\hline & Potamocypris arcuata Sars 1903 & 1 & & \\
\hline & P. fulva (Brady 1868) & 1 & & \\
\hline & P. smaragdina (Vavra 1891) & 1 & & \\
\hline & P. villosa (Jurine 1820) & 1 & & \\
\hline
\end{tabular}




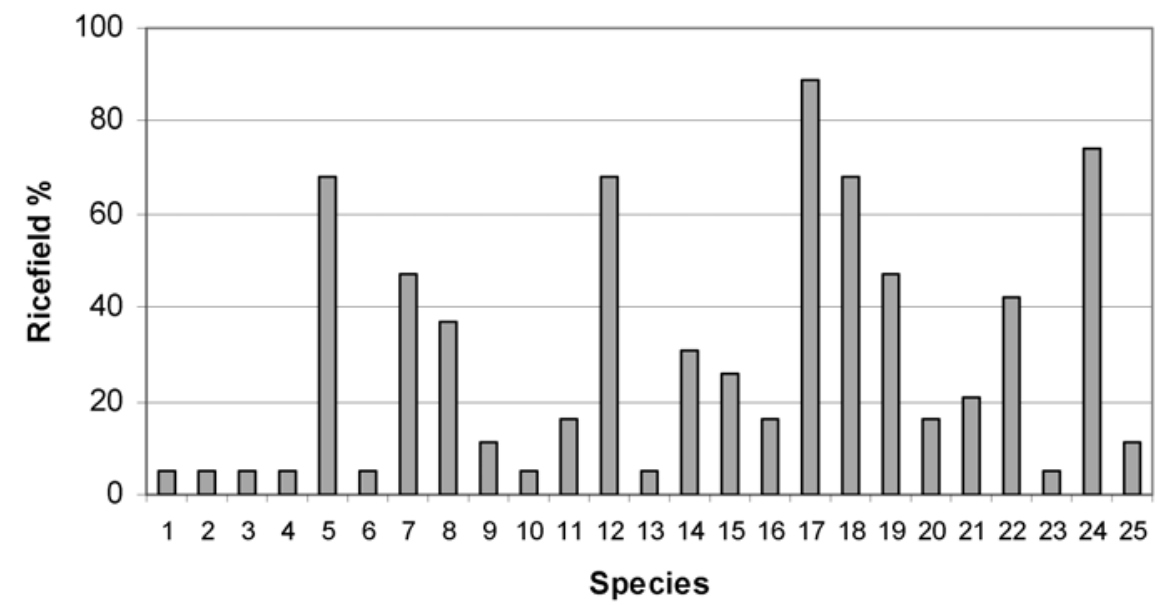

Fig. 2. For each 25 species recorded the percentage of presence in the 19 sampled ricefields is reported (see table 1).

To verify if the objects (ricefields) plot close to each other according to their geographical distribution, a regression analysis was performed between latitude and longitude and the numerical values (Dimensions 1 or 2) assigned to the cases (objects-ricefields).

Regression was performed between the species similarity index and geographical distance for each pairwise ricefield. Species similarity between pairwise ricefields was computed according to the formula:

$$
\frac{2 \mathrm{Nab}}{\mathrm{Na}+\mathrm{Nb}}
$$

where $\mathrm{Na}$ is the number of species detected in ricefield $\mathrm{a}, \mathrm{Nb}$ is the number of species detected in ricefield $\mathrm{b}$ and $\mathrm{Nab}$ is the number of species shared by ricefield a and b. Geographical distance between pairwise ricefields was computed according to the formula:

$$
\sqrt{\left(x_{a}-x_{b}\right)^{2}+\left(y_{a}-y_{b}\right)^{2}}
$$

where $\mathrm{x}$ and $\mathrm{y}$ are the latitude and longitude of each pairwise ricefield (ricefield a and ricefield $b$ ) expressed in decimal units.

All statistical analysis was performed using SPSS software.

\section{RESULTS}

The 25 ostracode species collected during 19941998 comprised one limnocytherid, four ilyocypridids, a candonid and 19 cypridids (Tab. 1). This represents a considerable diminution in number relative to the earlier sampling period. Further, only 19 species in the '60s were found again in the '90s survey.

The only candonid recorded previously that was found again in 1994-1998 was Pseudocandona albicans (Brady 1864) - a senior synonym of $P$. parallela (Müller 1900) recorded by Ghetti \& McKenzie (1981). The single limnocytherid was Limnocythere inopinata (Baird 1843); the four ilyocyprids included three species found in the earlier survey plus Ilyocypris monstrifica Norman, 1862. This latter species is a new record for Northern Italy. The 19 cypridid species include seven of the 13 "ospiti esteri" recorded by McKenzie \& Moroni (1986), plus Hemicypris dentatomarginata (Baird 1859) and Chrissia n. sp. both new records for Italy. Of the remaining 11 species, seven were recorded in the ' 60 s and two, Bradleystrandesia fuscata and Plesiocyprodopsis newtoni, represent other new records for the ricefields habitat. Like the limnocytherid, ilyocypridids, and the candonid all are common European species. The occasional occurrence of such common species in Italian ricefields is also referred to in Fox (1965).

Of the three new records: I. monstrifica was collected in a Piedmont ricefield (Saluggia); H. dentatomarginata was rather widespread, occurring in five ricefields of Piedmont, Lombardy, Venetia and Sardinia and Chrissia n. sp. was found in six Piedmont ricefields as well as in a Sardinian ricefield (Pontile).

Only two of the 25 species recorded in 1994-1998 are bisexual in Northern Italy, namely I. monstrifica and Pseudocandona albicans: both were found in only one ricefield, Saluggia (VC) and Livorno Ferraris (VC), respectively.

Five species - Cypridopsis vidua, Ilyocypris gibba, Dolerocypris sinensis, Heterocypris incongruens and Isocypris beauchampi cicatricosa - were recorded in more than $60 \%$ of the ricefields sampled, while $40 \%$ of the species were recorded in only one or two ricefields (Fig. 2). In two Western ricefields [Livorno Ferraris (VC) and Gionzana (NO)] $60 \%$ and $48 \%$ respectively of the total species were identified; whereas in four other ricefields [Villa Garibaldi (MN), Vigasio (VR), Cabras and Pontile (OR)] 20\% or less of the total species were collected (Fig. 3). 


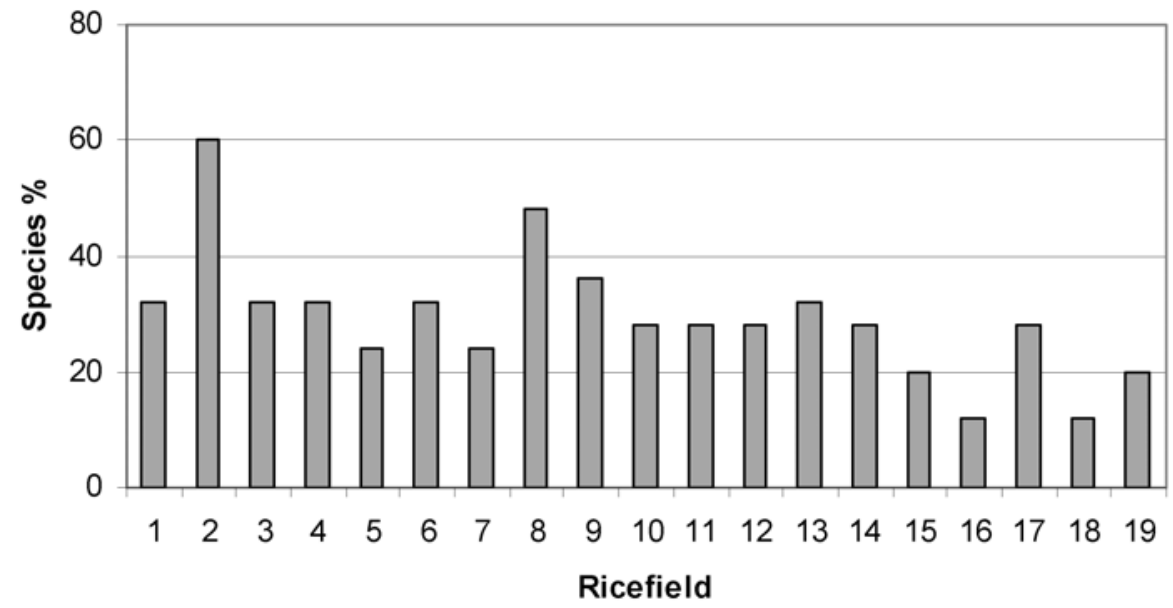

Fig. 3. For each 19 ricefields sampled the percentage of presence of the 25 species recorded is reported (see figure 1).

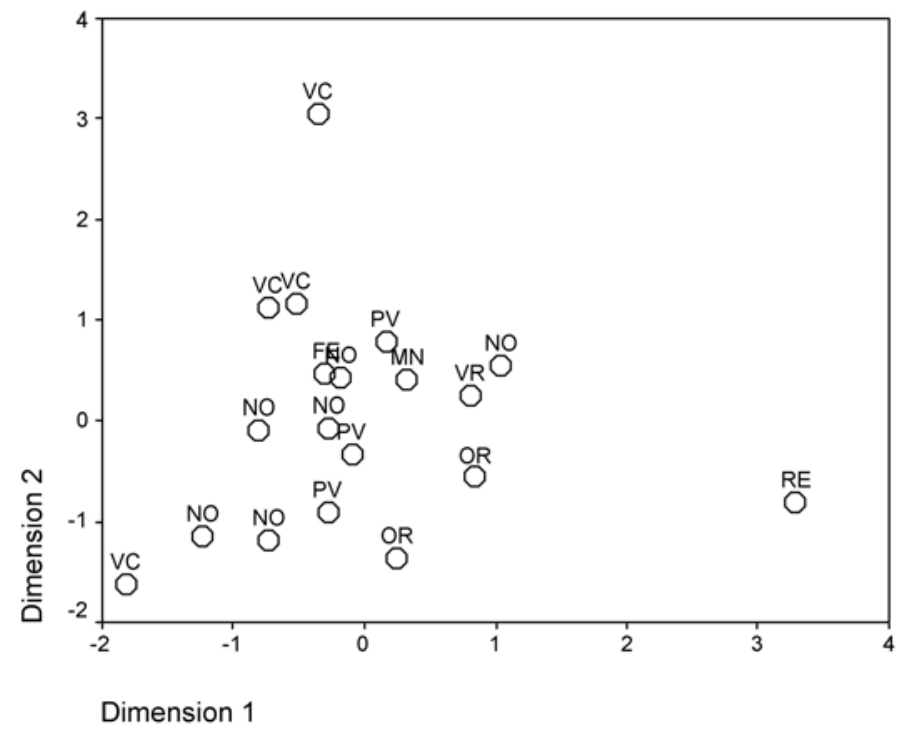

Fig. 4. Scattergram of 19 sampled ricefields according to homogeneity analysis (HOMALS). See figure 1 and $\S 2.1$. Statistical analysis.

The analysis of species composition (presence or absence of 25 species in different ricefields) does not permit the plotting of sites according their geographic distribution (Fig. 4). Neither Dimension 1 nor Dimension 2 is statistically correlated to latitude or longitude. Species similarity between ricefields is negatively related to geographic distance $\left(\mathrm{R}^{2}=0.26, \mathrm{~F}=579.980, \mathrm{p}>0.001\right)$ $(y=-0.05 x+0.58)$ (Fig. 5).

Considering the several provinces of the Po Plain region (Vercelli (VC), Novara (NO), Pavia (PV), Reggio Emilia (RE), Mantova (MN), Verona (VR) and Ferrara (FE)) the number of species per ricefields is, on average, higher in Western than in Eastern ricefields $(\mathrm{VC}=$ 9.8, $\mathrm{NO}=8.2, \mathrm{PV}=7.3, \mathrm{RE}=7, \mathrm{MN}=5, \mathrm{VR}=3, \mathrm{FE}=$ $7)$. However correlation between the species richness of an individual ricefield and longitude is not statistically significant $\left(\mathrm{R}^{2}=0.18, \mathrm{~F}=3.717, \mathrm{p}=0.071\right)$. On the other hand, the number of species per province is significantly related to the amount of area devoted to rice cultivation $\left(\mathrm{R}^{2}=0.67, \mathrm{~F}=10.902, \mathrm{p}=0.021\right)(\mathrm{y}=$ $0.0001 x+5.90)$ (Fig. 6).

\section{DISCUSSION}

During the last 30 or so years, the number of ostracode species in the ricefield of Northern Italy, based on our collections, has decreased from 46 to 25 , and only 19 species recorded in the ' 60 s were found once again in 1994-1998 (Tab. 1). Even allowing for possible synonymies in the earlier work, this represents a considerable diminution. Three species were recorded for the 


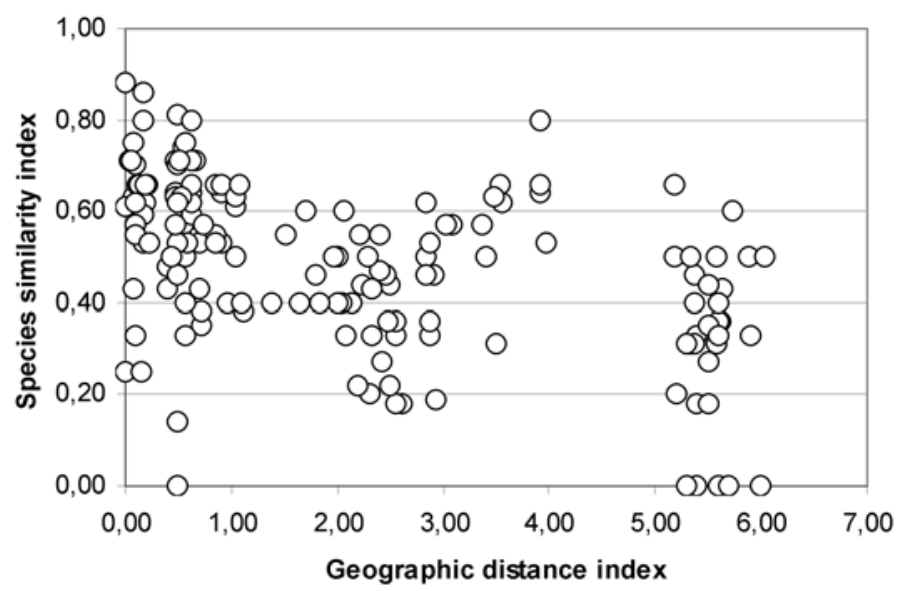

Fig. 5. The relationship between species similarity index and geographic distance index between each pair of ricefields. See $\S 2.1$. Statistical analysis.

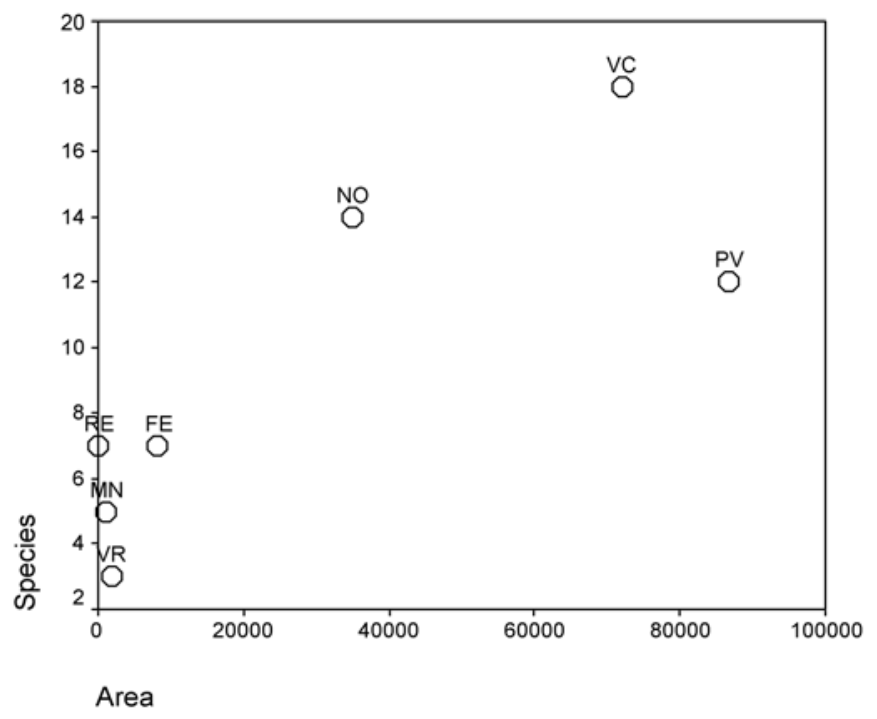

Fig. 6. The relationship between species richness and rice-cultivated surface area (hectares) in Northern Italian provinces.

first time in Italy: Ilyocypris monstrifica, Chrissia sp. and Hemicypris dentatomarginata. Two other species, Bradleystrandesia fuscata and Plesiocyprodopsis newtoni, though not listed for ricefields by McKenzie \& Moroni (1986), were included in the Italian ostracode fauna by Ghetti \& McKenzie (1981).

Among the 27 species found in the '60s but not recorded during 1994-1998, Limnocythere cf. stationis, Ilyocypris inermis, Cypretta minna, Strandesia caudata, S. tonolli and Potamocypris smaragdina have been described, in Italy, only from the ricefield habitat (Veneri 2001). Most of these species, apart from Cypretta dubia and Cypridopsis obesa, were present in less than $20 \%$ of the ricefields sampled and occurred in Eastern ricefields that, thirty years ago, were the most rich in species.
In the ' $60 \mathrm{~s}$, the most widespread species, recorded in $50 \%$ of the ricefields, were Dolerocypris sinensis and Tanycypris pellucida. In the '90s, D. sinensis further increased its diffusion (68\% of ricefields, in Piedmont, Lombardy, Emilia-Romagna and Venetia), while $T$. pellucida was found in only $21 \%$ of the ricefields (Piedmont and Lombardy). In fact, during 1994-1998 many species increased their diffusion in quantitative terms (percentage of presence per ricefield) as well as in qualitative terms (presence in more than one region). In the ' 60 s, only 7 species were recorded in $20-40 \%$ of ricefields (Ilyocypris biplicata, Cypretta dubia, Heterocypris incongruens, Stenocypris major, Strandesia spinulosa, Cypridopsis obesa and C. vidua) and $61 \%$ of the total species were found in only one or two ricefields. Today, $H$. incongruens is the most widespread species 
( $89 \%$ of ricefields) and, beside $D$. sinensis, several other species were found in more than $50 \%$ of the ricefields sampled - C. vidua (74\%), Ilyocypris gibba (68\%) and Isocypris beauchampi cicatricosa (68\%). Moreover, $40 \%$ of the species occur in just one or two ricefields. $H$. incongruens, $C$. vidua and $I$. gibba are the most widespread non-marine species in Italy, while I. biplicata, Chlamydotheca incisa and Chrissia sp. are all considered typical of the ricefield habitat today (Veneri 2001). The widespread and massive use of fertilisers, pesticides and herbicides in Northern Italy, which initiated in the early '60s (www.enterisi.it) may be related, per se, to the observed decrease in species richness as documented in similar cases (Kawatski \& Schmulbach 1971; Kawatski 1973; Fernando 1993; Dodson et al. 2000; Hanazato 1998). On the other hand, some species (S. major and C. vidua, for instance) seem particularly resistant to pesticides such as carbofuran and endosulfan (Lim \& Wong 1986), and $H$. incongruens is very tolerant of organic pollution (Mezquita et al. 1999). Thus, the dramatic modification of agricultural practices may rather have influenced interspecies competition and so led to a decline in species number.

Of a total of 13 "ospiti esteri" listed by McKenzie \& Moroni (1986) only seven were found again in the '90s while two new species considered foreign in origin were recorded: Chrissia sp. and $H$. dentatomarginata. The former was found in the ricefields of Piedmont and Sardinia. The genus Chrissia was first described from Africa (Hartmann 1957) and also occurs in India and Malaysia (Victor \& Fernando 1981, 1982). This is the first record of Chrissia in the Mediterranean region. H. dentatomarginata is an Indian species (Victor \& Fernando 1981; Martens \& Wouters 1985) that was found in the ricefields of Piedmont, Lombardy and Sardinia.

The recording of these species indicates once again the importance of man as an agent for passive dispersal of ostracode and cladoceran and the role of ricefields as a suitable habitat for new exotic colonising species (McKenzie \& Moroni, 1986; Margaritora et al. 1987; Ferrari et al. 1991; Leoni et al. 1999). We note that at least three of the none "ospiti esteri" species recorded in the '90s survey also occur in Italian temporary ponds and lakes. The third new record from our work, I. monstrifica is a well known European species. Additionally to our record, a bisexual population has been collected from a temporary pond in Sicily (G. Gentile, pers. comm.) and yet another population was recorded recently in Lombardy (G. Rossetti, pers. comm.). The only other bisexual species recorded during 1994-1998, as we noted earlier, is Pseudocandona albicans, and apart from our ricefields data its records from temporary ponds and lake also are all bisexual (Veneri 2001), as is typical for Italian candonids (Ghetti \& McKenzie 1981). Two other species, Eucypris virens and H. incongruens, are parthenogenetic in Northern Italian ricefields but bisexual in temporary ponds in the South (Sicily and
Pelagie Islands) (Crosetti \& Margaritora 1982; Bellavere et al. 1999; Schön et al. 2000).

In general, ricefields and temporary ponds are the habitats richest in species in Northern Italy and share many species (Veneri 2001). Such results may be related to the productivity and seasonal heterogeneity of these habitats (Begon et al. 1996) and suggest that small temporary freshwater ponds and the ricefields distributed across a landscape act as "stepping-stones" for dispersing ostracode species and may be analogous to islands as indicated above. According to island biogeography theory, the number of species on an island should increase with island size and decrease with island distance from the mainland (McArthur \& Wilson 1967). We tested an hypothesis that the spatial functioning of these taxa is driven by species that enter the population through a "stepping-stone" colonising model, and then radiate away from the richer Eastern community by dispersal, thus creating a spatial pattern that would reflect the geographic distribution of the ricefields. In fact, no such spatial pattern was observed and the ricefields are not structured according to species similarity. This may be due to the fact that, in taxa such as ostracodes, the production of diapausing eggs capable of passive dispersal constrains regional differentiation. On the other hand, we observed that the number of species is significantly related to the amount of surface area devoted to rice cultivation in the provinces of Northern Italy. Moreover, the ostracode community in distant ricefields is more distinct than in ricefields that are closer together. The number of species per ricefield decreases from West to East according to a longitudinal cline in the amount of rice-cultivated area per province. This cline could be the result of historical factors. Since the $15^{\text {th }}$ Century (Simon 2001), rice cultivation has become relatively widespread, especially in Piedmont and Lombardy and, as noted earlier, a further boost occurred in the second half of the $19^{\text {th }}$ Century in Piedmont. But this seems in contrast to the observation reported above, that in the ' 60 s the Eastern ricefields were the most rich in species.

In general, we can conclude that the dispersal of species among habitat patches, and in particular humanmediated ones, local interaction and historical factors all may have had a role in affecting the richness and biogeography of non-marine ostracodes in Northern Italy.

In 1992, Baltanas compared the richness in cypridid ostracode faunas of adjacent Mediterranean areas: the Iberian Peninsula, France, Italy and North Africa. Bringing his Italian data up to date (Veneri 2001), 51\% of Cyprididae species found in Italy are from ricefields and $7 \%$ are typical of this habitat. We end by suggesting that the higher number of Cyprididae species found in Italy may be related to the greater rice-cultivated area in our country $(200,000$ ha) with respect to France $(18,700$ ha), Portugal (23,000 ha) and Spain (114,300 ha) (www.enterisi.it). 


\section{ACKNOWLEDGMENTS}

We wish to thank G. Gentile and P. Giordano for assistance in sampling, and F. Sartore for assistant in statistical analysis. The study was supported financially by the Italian Ministero dell'Università e della Ricerca Scientifica (FIL 2001).

\section{REFERENCES}

Baltanas, A. 1992. A contribution to the knowledge of the cypridid ostracode fauna (Crustacea, Ostracoda, Cyprididae) on the Iberian peninsula, and a comparison with adjacent areas. Arch. Hydrobiol./Suppl., 90, 3: 419-452.

Begon, M., J.L. Harper \& C.R. Townsend. 1996. Ecology. Blackwell Science.

Bellavere, C., G. Benassi, K.G. McKenzie \& V. Rossi 1999. Non-marine Ostracoda (Crustacea) from temporary ponds in the Isole Pelagie (Sicily, Italy). Geosound, 35: 29-38.

Bilton, D.T., J.R. Freeland \& B. Okamura. 2001. Dispersal in freshwater invertebrates. Annu. Rev. Ecol. Syst., 32: 159-181.

Bronshtein, Z.S. 1947. Fresh-water Ostracoda. Fauna of the USSR. Crustaceans. Vol. II, num. 1, Academy of Sciences of the USSR Publishers, Moscow: $470 \mathrm{pp}$.

Crosetti, D. \& F.G. Margaritora. 1982. Osservazioni su popolazioni anfigoniche di Eucypris virens (Jur.) (Crustacea, Ostracoda) rinvenute in Sicilia. Animalia, 9 (1/3): 123-129.

Danielopol, D.L. 1982. The preparation of ostracods limbs for otical microscopy (dissection, staining and mounting procedures). In: R.F. Maddocks (Ed.), 8th International Symposium on Ostracoda. Applications of Ostracoda to economic and scientific problems. Program and Abstract: 4143. Univ. Of Houston, Dept. Geosciences Houston, TX.

Dodson, S.I., S.E. Arnott \& K.L. Cottingham. 2000. The relationship in lake communities between primary productivity and species richness. Ecology, 81: 2662-2679.

Fernando, C.H. 1993. Ricefield ecology and fish culture - an overview. Hydrobiologia, 259: 91-113.

Ferrari, I., A. Bachiorri, F.G. Margaritora \& V. Rossi. 1991. Succession of cladocerans in a Northern Italian ricefield. Hydrobiologia, 225: 309-318.

Fox, H.M. 1963. A new species of Isocypris (Crustacea, Ostracoda) from the Lago Maggiore and a new subspecies from ricefields in Piedmont. Mem. Ist. ital. Idrobiol., 16: 127-136.

Fox, H.M. 1965. Ostracod Crustacea from ricefields in Italy. Mem. Ist. ital. Idrobiol., 18: 205-214.

Ghetti, P.F. \& K.G. McKenzie 1981. Ostracodi (Crustacea, Ostracoda). Guide per il riconoscimento delle specie animali delle acque interne italiane. C.N.R. AQ/1/108, 11: 83 pp.

Hanazato, T. 1998. Response of a zooplankton community to insecticide application in experimental ponds: a review and the implications of the effects of chemicals on the structure and functioning of freshwater communities. Environ. Pollut., 101: 361-373.

Hartmann, G. 1957. Ostrakoden aus dern Namaland und Transsvaal. Ver. auff Natura. Ver. Osnabruck., 28: 50-60.

Kawatski, J.A. 1973. Acute toxicities of Antimycin A, Bayer 73, and TFM to the ostracod Cypretta kawatai. Trans. Am. Fish. Soc., 102: 829-831.

Kawatski, J.A. \& C. Schmulbach 1971. Accumulation of insecticide in freshwater ostracods exposed continuously to sublethal concentrations of Aldrin or Dieldrin. Trans. Am. Fish. Soc., 100: 565-567.

Klie, W. 1938. Ostracoda, Muschelkrebse. In: F. Dahl (Ed.), Die Tierwelt Deutschlands. Vol. 34. Gustav Fischer, Jena: $230 \mathrm{pp}$.
Leoni, B., M. Cotta-Ramusino \& F.G. Margaritora 1999. Seasonal succession of Cladocerans in a ricefield in Italy. Hydrobiologia, 391: 241-247.

Lim, R.P. \& M.C. Wong 1986. The effects of pesticides on the population dynamics and production of Stenocypris major Baird (Ostracoda) in ricefields. Arch. Hydrobiol., 106: 421-427.

Margaritora, F.G., I. Ferrari \& D. Crosetti 1987. A far east Moina, M. weismanni, Ishikawa 1896, found in a Italian ricefield. Hydrobiologia, 145: 93-103.

Martens, K. (Ed.). 1998. Sex and parthenogenesis, evolutionary ecology of reproductive modes in non-marine Ostracoda (Crustacea). Backhuys Publishers, Leiden, The Netherlands.

Martens, K. \& K. Wouters. 1985. On Hemicypris dentatomarginata (Baird). Stereo-Atlas of Ostracod Shells, 12: 127-134.

McArthur, R. \& E.O. Wilson. 1967. The theory of Island Biogeography. Princeton University Press.

McKenzie, K.G. \& A. Moroni. 1986. Man as an agent of Crustacean passive dispersal via useful plants - exemplified by Ostracoda "ospiti esteri" of the Italian ricefields ecosystem - and implications arising therefrom. J. Crustacean Biol., 6: 181-198.

Meisch, C. 1984. Revision of the recent Western Europe species of genus Potamocypris (Crustacea, Ostracoda). Part. I: Species with short swimming setae on the second antennae. Traveaux Scientifiques du Musée d'Histoire Naturelle de Luxembourg, III: 55 pp.

Meisch, C. 1985. Revision of the recent Western Europe species of genus Potamocypris (Crustacea, Ostracoda). Part. II: Species with long swimming setae on the second antennae. Traveaux Scientifiques du Musée d'Histoire Naturelle de Luxembourg, VI: $95 \mathrm{pp}$.

Meisch, C., K. Wooters \& K. Martens. 1990. Liste annotée des Ostracodes actuels non-marins trouvés en France (Crustacea, Ostracoda). Ministere des Affaires Culturelles, XV:1-62.

Mezquita, F., H.I. Griffiths, S. Sanz, J.M. Soria \& A. Pinon 1999. Ecology and distribution of ostracods associated with flowing waters in the Eastern Iberian. J. Crustacean Biol., 19: 344-354.

Moroni, A. 1967a. Ostracodi delle risaie italiane. Sistematica, ecologia, distribuzione geografica. Ed. Studium Parmense, Parma.

Moroni, A. 1967b. Ricerche ecologiche sulle acque astatiche. Ecologia delle comunità eleoplanctoniche di risaia. Ed. Studium Parmense, Parma.

Moroni, A. 1967c. Ricerche sulle acque astatiche. L'ecosistema di risaia. Boll. Zool., 34: 145-146.

Sars, G.O. 1928. An account of the Crustacea of Norway. Ostracoda. Vol. IX. Bergen Museum, Oslo.

Schön, I., A. Gandolfi, E. Di Masso, V. Rossi, H.I. Griffiths, K. Martens \& R.K. Butlin. 2000. Persistence of asexuality through mixed reproduction in Eucypris virens (Crustacea, Ostracoda). Heredity, 84: 161-169.

Shurin, J.B., J.E. Havel, M.A. Leibold \& B. Pinel-Alloul. 2000. Local and regional zooplankton species richness: a scale-indipendent test for saturation. Ecology, 81: 30623073.

Simon, K. 2001. I Gonzaga storia e segreti. Newton \& Compton, Rome, Italy.

Veneri, M. 2001. Gli Ostracodi non marini in Italia. 1st Degree thesis, Università di Parma.

Victor, R. \& C.H. Fernando. 1981. An illustrated key to the freshwater Ostracod genera of the Oriental region. Biology series, 23. University of Waterloo, Ontario, Canada.

Victor, R. \& C.H. Fernando 1982. Distribution of freshwater Ostracoda (Crustacea) in Southeast Asia. J. Biogeogr., 9: 281-288. 